\title{
Pengaruh Faktor-Faktor Individual Terhadap Perilaku Etis Auditor Pada Inspektorat Provinsi Gorontalo
}

\author{
YUSRIN ABDUL ${ }^{1}$, JULLIE J. SONDAKH ${ }^{2}$, JANTJE J. TINANGON ${ }^{3}$ \\ 1,2,3 Program Magister Akuntansi, Fakultas Ekonomi dan Bisnis Universitas Sam Ratulangi \\ email: yursinabdul@gmail.com ${ }^{1}$, julliesondakh@gmail.com², jantjetinangon1163@gmail.com ${ }^{3}$
}

\begin{abstract}
This study aims to know and analyze the effects of individual factors namely internal locus of control, intellectual intelligence, emotional intelligence, and spiritual intelligence on the ethical behavior of the Gorontalo Provincial Inspectorate auditors. This is a quantitative research. The population in this study was all staff of the Gorontalo Provincial Inspectorate. Samples are auditors having certification of the Auditor's Functional Position (JFA). This study included 44 respondents. Data were collected by questionnaires. Data were analysed by multiple regression and SPSS program. The results of the study showed that an internal locus of control affects increasing auditor ethical behavior. Intellectual intelligence (IQ) increases auditor ethical behavior. Emotional Intelligence (EQ) increases auditor ethical behavior. Spiritual Intelligence $(S Q)$ does not increase the auditor's ethical behavior.
\end{abstract}

Keywords: Internal Locus of Control, Intellectual Intelligence, Emotional Intelligence and Spiritual Intelligence on the Ethical Behavior

\begin{abstract}
Abstrak. Penelitian ini bertujuan untuk mengatahui dan menganalisis pengaruh faktor-faktor individual yakni locus of control internal, kecerdasan intelektual, kecerdasan emosional dan kecerdasan spiritual terhadap perilaku etis auditor Inspektorat Provinsi Gorontalo. Jenis penelitian ini adalah penelitian kuantitatif. Populasi dalam penelitian ini adalah seluruh pegawai Inspektorat Provinsi Gorontalo dengan sampel penelitian yakni auditor memiliki sertifikasi Jabatan Fungsional Auditor (JFA) yang berjumlah 44 responden. Metode pengumpulan data menggunakan kuesioner dengan menggunakan analisis data regresi berganda dengan bantuan SPSS. Hasil penelitian menunjukkan Locus of Control Internal berpengaruh dalam meningkatkan perilaku etis auditor. Kecerdasan Intelektual (IQ) berpengaruh dalam meningkatkan perilaku etis auditor. Kecerdasan Emosional (EQ) berpengaruh dalam meningkatkan perilaku etis auditor. Kecerdasan Spiritual (SQ) tidak berpengaruh dalam meningkatkan perilaku etis auditor.
\end{abstract}

Kata kunci : Locus of Control Internal, Kecerdasan Intelektual, Kecerdasan Emosional, Kecerdasan Spiritual, Perilaku Etis

\section{Pendahuluan}

Inspektorat Provinsi Gorontalo merupakan unsur pengawas penyelenggaraan Pemerintahan Daerah yang dipimpin oleh inspektur bertanggung jawab langsung kepada Gubernur, mempunyai tugas melakukan pengawasan terhadap pelaksanaan urusan Pemerintahan di Daerah, pelaksanaan pembinaan atas penyelenggaraan Pemerintahan Daerah kabupaten/kota dan pelaksanaan urusan pemerintahan di Daerah kabupaten/kota. Dalam melaksanakan tugas tersebut. Inspektorat merupakan unsur penunjang pemerintah yang secara umum diataur dalam pasal 4 Peraturan Menteri Dalam Negeri No. 64 tahun 2007. Dalam pasal tersebut dinyatakan bahwa dalam melaksanakan tugas pengawasan urusan pemerintahan, inspektorat provinsi mempunyai fungsi : a. perencanaan program pengawasan; b. perumusan kebijakan dan fasilitasi pengawasan;dan c. pemeriksaan, pengusutan, pengujian, dan penilaian tugas pengawasan.

Kegiatan pengawasan internal dilakukan oleh auditor internal pada Inspektorat Provinsi Gorontalo yang juga disebut Aparat Pengawasan Intern Pemerintah (APIP) yang melaksanakan kegiatan pengendalian internal dalam kerangka Sistem Pengendalian Intern Pemerintah (SPIP) terdiri dari kegiatan audit, review, 
evaluasi, pemantauan dan kegiatan pengawasan lainnya. Pengawasan bersifat membantu agar sasaran yang ditetapkan Pemerintah Provinsi Gorontalo dapat tercapai, dan secara dini menghindari terjadinya penyimpangan pelaksanaan, penyalah gunaan wewenang, pemborosan dan kebocoran.

Kesuksesan Inspektorat Provinsi Gorontalo ditentukan oleh laporan hasil pemeriksaan Provinsi Gorontalo oleh auditor eksternal dalam hal ini Badan Pemeriksa Keuangan (BPK) yang juga dilaksanakan setiap tahun. Hingga tahun 2017, Pemerintah Provinsi Gorontalo meraih opini Wajar Tanpa Pengecualian (WTP) atas Laporan Keuangan Pemerintah Daerah (LKPD) oleh Badan Pemeriksa Keuangan (BPK) RI. Capaian tersebut menjadi prestasi yang ke enam kalinya secara berturut-turut selama enam tahun terakhir. Keberhasilan tersebut tentu tidaklah mudah, peran Inspektorat Provinsi Gorontalo memiliki andil yang besar dalam mewujudkan hal tersebut. Akan tetapi, dibalik opini WTP tersebut auditor BPK masih memenemukan beberapa permasalahan yang penting untuk ditindak lanjuti oleh Pemerintah Provinsi Gorontalo, diantaranya sehubungan dengan penyaluran dana Bantuan Operasional Sekolah (BOS), pencatatan penggunaan hibah dari Pemerintah Pusat ke Pemerintah Provinsi, penataan asset tetap dan lainlain (BPK RI, http://mediacerdasbangsa.com: 2018).

Bagi Inspektorat Provinsi Gorontalo, hasil temuan BPK tersebut menjadi bahan evaluasi kinerja auditor atas penerapan Sistem Pengendalian Internal, sebab hasil temuan tersebut harusnya dapat dideteksi sejak dini oleh auditor internal sehingga tidak menjadi temuan auditor BPK. Untuk itu, capaian kinerja auditor tidak terlepas dari dua aspek, yakni efektivitas penerapan standar audit dan kepatuhan auditor terhadap kode etik auditor APIP. Efektivitas penerapan standar audit pada Inspektorat Provinsi Gorontlao dapat dinilai pada hasil evalusi kinerja auditor hingga pada tingkat kemandirian APIP, namun hal ini tidak terjadi pada kode etik. Kode etik APIP secara jelas diatur dalam Peraturan Menteri Negara Pendayagunaan Aparatur Negara Nomor 4 Tahun 2008. Sampai dengan saat ini belum ada form penilaian tersendiri terhadap kode etik auditor APIP walaupun masalah kode etik dibahas tersendiri dan sedetail mungkin pada setiap pelatihan atau Diklat auditor.

Tuntutan terhadap penilaian tersendiri atas penerapan kode etik APIP sangat dibutuhkan. Sebab secara empiris, kode etik APIP dapat meningkatkan kinerja auditor pemerintah (Kneefel, dkk., 2017). Hal inilah yang dapat menjadi celah permasalahan-permasalahan etika pada Auditor Ispektorat Provinsi Gorontalo, sehingga masalah etika masih banyak bertumpu pada kepribadian individu auditor, belum sepenuhnya pada tuntutan kode etik APIP tanpa ada barometer yang jelas. Kondisi ini berdampak pada rendahnya tanggung jawab individu auditor dalam setiap tugas yang diberikan, yang semestinya dibutuhkan kesungguhan disetiap pekerjaan. Masih rendahnya kerjasama tim dalam pelaksanaan tugas, masih ditemui perasaan dan sikap saling iri, komunikasi yang kurang fleksibel, hubungan emosional auditor dengan auditi baik dalam hal hubungan keluarga, relasi, teman yang berpotensi mempengaruhi sikap independensi seorang auditor dalam penugasan, serta permasalahan etika lainnya yang didominasi menyangkut integritas seorang auditor APIP.

Oleh karena itu, aspek perilaku etis memiliki peran penting didalam meningkatkan kinerja auditor Inspektorat Provinsi Gorontalo. Namun demikian, perilaku setiap auditor tentu dapat saja berubah dan perubahan perilaku tersebut tentu terdapat hal-hal yang dapat mempengaruhinya. Secara empiris, faktorfaktor individual terbukti merupakan faktor yang signifikan untuk memprediksi perilaku etis seseorang terutama pada saat tidak terjadi konflik situasi atau adanya faktor situasi yang rendah. Bahkan faktor-faktor individual merupakan faktor yang paling berpengaruh terhadap perilaku etis seseorang (Reiss dan Mitra, 1998). Faktor-faktor individual yang dimiliki setiap orang tentu sangat beragam. Pada penelitian ini, digunakan faktor-faktor individual yang memiliki relevansi terhadap perubahan perilaku pada objek yang diteliti yakni perilaku etis Auditor Inspektorat Provinsi Gorontalo, yakni lebih fokus membahas faktor individual locus of control internal, kecerdasan intelektual, kecerdasan emosional dan kecerdasan spiritual.

Locus of control memiliki keterkaitan terhadap sikap independensi seorang auditor yang tidak dipengaruhi dan tidak ketergantungan terhadap siapapun dalam melaksanakan tugas audit (Mulyadi, 2010:87). Locus of control merupakan cara pandang seseorang terhadap sesuatu peristiwa apakah dia dapat atau tidak dapat mengendalikan (control) peristiwa yang terjadi padanya (Rotter, 1996). Selain itu juga, seorang auditor juga dituntut memiliki kompetensi dan integritas. Dimana, standar kompetensi seorang auditor mencakup aspek pengetahuan (knowledge), keterampilan/ keahlian (skill), dan sikap prilaku 
(attitude) (Agoes, 2013:146). Sedangkan integritas seorang auditor dapat mencakup sikap jujur, bertanggung jawab, kesadaran diri dan tidak merugikan orang lain (Mulyadi, 2010:56). Oleh karena itu, kompetensi dan integritas seorang auditor memiliki keterkaitan terhadap tingkat keceradan intelektual (IQ), kecerdasan emosional (EQ) dan kecerdasan spiritual (SQ) seorang auditor.

Seseorang yang memiliki tingkat kecerdasan intelektual tentu memiliki pengetahuan (knowledge) dan keterampilan/ keahlian (skill). Sedangkan sesorang yang memiliki tingkat kecerdasan emosional dan spiritual selalu menjaga prilaku (attitude), sikap jujur, bertanggung jawab, memiliki kesadaran diri dan tidak merugikan orang lain. Manusia memiliki tiga kecerdasan utama yakni kecerdasan intelektual, emsional dan spiritual, dimana kecerdasan spiritual menjadi landasan yang diperlukan untuk memfungsikan kecerdasan intelektual dan kecerdasan emosional (Zohar dan Marshall, 2007:4).

Berdasarkan hal-hal tersebut di atas maka peneliti menggunakan locus of control internal, kecerdasan intelektual, kecerdasan emosional dan kecerdasan spiritual sebagai faktor-faktor individual dalam menganalisis pengaruhnya terhadap perilaku etis Pada Inspektorat Provinsi Gorontalo.

Berdasarkan latar belakang penelitian tersebut, maka yang menjadi rumusan masalah dalam penelitan ini adalah :

1. Apakah locus of controlinternal berpengaruh didalam meningkatkan perilaku etis Auditor Inspektorat Provinsi Gorontalo?

2. Apakah kecerdasan intelektual berpengaruh didalam meningkatkan perilaku etis Auditor Inspektorat Provinsi Gorontalo?

3. Apakah kecerdasan emosional berpengaruh didalam meningkatkan perilaku etis Auditor Inspektorat Provinsi Gorontalo?

4. Apakah kecerdasan spiritual berpengaruh didalam meningkatkan perilaku etis Auditor Inspektorat Provinsi Gorontalo?

Adapun yang menjadi tujuan penelitian ini adalah untuk mengetahui dan menganalisis pengaruh locus of control internal, kecerdasan intelektual, kecerdasan emosional, kecerdasan spiritual terhadap perilaku etis Auditor Inspektorat Provinsi Gorontalo. Penelitian ini dapat memberikan manfaat bagi Pimpinan Inspektorat Provinsi Gorontalo dalam bentuk rekomendasi yang didasarkan pada penelitian tentang faktor-faktor individual dan perilaku etis Auditor Inspektorat Provinsi Gorontalo, dalam upaya meningkatkan karakter Auditor yang professional, beretika dan berintegritas. Bagi dunia akademisi sebagai referensi riset dan pengembangan riset lebih lanjut terutama hal-hal yang berhubungan dengan faktor-faktor individual dan perilaku Auditor, serta didalam meningkatkan pemahaman dan wawasan tentang aspek perilaku etis Auditor dan faktor-faktor individual yang mempengaruhinya.

Gambar 1.1 Kerangka Konseptual Penelitian

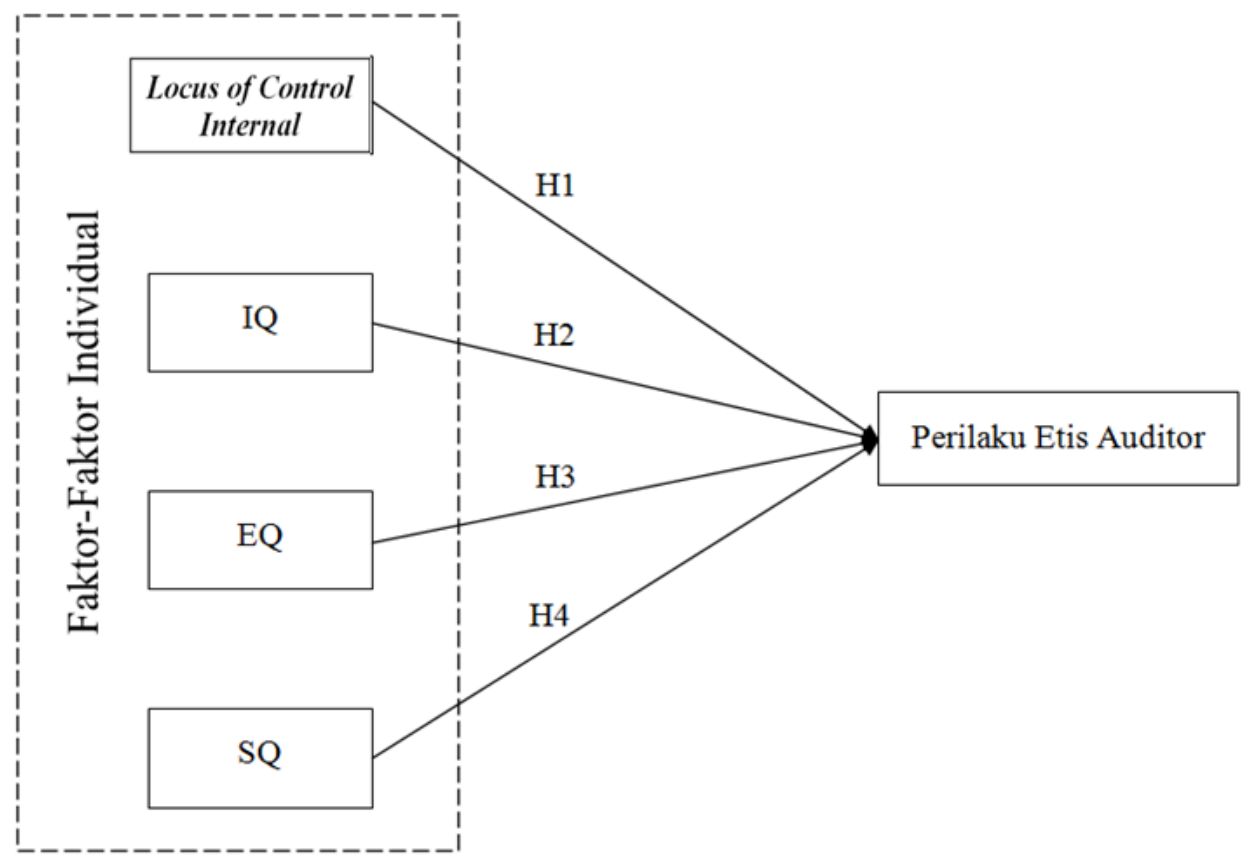


Berdasarkan teori-teori dan penelitian terdahulu maka dapat dirumuskan hipotesis sebagai berikut:

\section{Pengaruh Locus of Control Internal Terhadap Perilau Etis}

Menurut Robbins (2011:56) locus of control adalah sampai sejauh mana orang yakin bahwa mereka menguasai nasib mereka sendiri. Locus of control merupakan konsep yang beranggapan bahwa suatu kepercayaan seseorang terkait akan perilaku serta konsekuensi yang akan dihadapinya. Menurut Jones dan George (2011:111) orang dengan internal locus of control percaya bahwa mereka sendirilah yang memiliki kendali atas takdir mereka sendiri, yakni mereka melihat bahwa tindakan dan perilaku mereka sendiri yang menjadi penentu utama dan pasti dalam mencapai suatu hasil yang penting. Sedangkan orang dengan eksternal locus of control percaya bahwa pihak luarlah yang memiliki tanggung jawab atas takdir mereka dan yang terjadi disekitar mereka. Mereka merasa bahwa tindakan mereka tidak memberikan perbedaan yang berarti sehingga mereka cenderung tidak ikut campur mengubah suatu situasi atau memecahkan masalah dan menyerakannya kepada orang lain.

Penelitian Raharjo (2013) pada Kantor Akuntan Publik di Semarang menunjukan bahwa locus of control dapat mempengaruhi perilaku etis auditor, dimana semakin internal locus of control yang dimiliki seorang auditor, maka akan semakin meningkatkan perilaku etisnya. Penelitian Helmayunita (2015) juga pada Kantor Akuntan Publik di Kota Padang dan Pekanbaru juga menunjukan hasil bahwa locus of control internal berpengaruh signifikan terhadap perilaku etis akuntan. Dimana semakin tinggi tingkat locus of control internal yang dimiliki seorang akuntan maka akan meningkatkan perilaku etisnya dalam melaksanakan tanggungjawab sebagai profesional akuntan.

\section{$\mathrm{H}_{1}$ : Locus of control internal berpengaruh didalam meningkatkan perilaku etis}

\section{Pengaruh Kecerdasan Intelektual Terhadap Perilau Etis}

Menurut Robbins dan Judge (2008:56) kecerdasan intelektual merupakan kemampuan yang dibutuhkan untuk melakukan berbagai aktivitas mental perpikir, nalar, dan memecahkan masalah. Individu dalam sebagain besar masyarakat menempatkan kecerdasan dan untuk alasan yang tepat, pada nilai yang tinggi. Individu cerdas biasanya mendapatkan lebih banyak uang dan tingkat pendidikan lebih tinggi. Individu yang cerdas lebih mungkin menjadi pemimpian dalam suatu kelompok. Kecerdasan intelektual biasa juga disebut sebagai intelegensi (intellgence), dimana Binet \& Simon (dalam Azwar, 2004) mendefinisikan intelegensi sebagai suatu kemampuan yang terdiri dari 3 komponen, yaitu: kemampuan untuk mengarahkan pikiran atau mengarahkan tindakan; kemampuan untuk mengubah arah tindakan bila tindakan itu telah dilakukan; dan kemampuan untuk mengkritik diri sendiri.

Hasil penelitian Riasning, Datrini, dan Putra (2017) pada mahasiswa akuntansi di kota Denpasar menunjukan bahwa kecerdasan intelektual memberikan pengaruh yang signifikan terhadap sikap etis mahasiswa akuntansi. Dimana semakin tinggi tingkat kecerdasan intelektual yang dimiliki mahasiswa maka akan semakin tinggi pula sikap etis mahasiswa tersebut. Penelitian Su'udiyah (2017) pada mahasiswa akuntansi di Perguruan Tinggi Negeri dan Swasta di Jakarta, yang menunjukan hasil yang sama dimana kecerdasan intelektual berpengaruh signifikan terhadap sikap etis mahsiswa akuntansi. Tingkat kecerdasan intelektual mahasiswa dapat meningkatkan perilaku etis mahasiswa.

\section{$\mathbf{H}_{2}$ : Kecerdasan intelektual berpengaruh didalam meningkatkan perilaku etis}

\section{Pengaruh Kecerdasan Emosional Terhadap Perilau Etis}

Menurut Goleman (2009:45) kecerdasan emosi merupakan kemampuan emosi yang meliputi kemampuan untuk mengendalikan diri, memiliki daya tahan ketika menghadapi suatu masalah, mampu mengendalikan impuls, memotivasi diri, mampu mengatur suasana hati, kemampuan berempati dan membina hubungan dengan orang lain. Salovey dan Mayer (1990) menjelaskan kecerdasan emosi merupakan kemampuan untuk memonitor perasaan dan emosi diri sendiri dan orang lain, membedakan 
emosi dan perasaan, dan menggunakan informasi tersebut untuk menuntun pemikiran dan tindakan (dalam Luthans, 2006:332).

Penelitian Riasning, dkk. (2017) pada mahasiswa akuntansi dikota Denpasar membuktikan bahwa kecerdasan emosi memberikan pengaruh yang signifikan terhadap sikap etis mahasiswa akuntansi. Semakin tinggi tingkat kecerdasan emosi yang dimiliki mahasiswa maka akan semakin tinggi pula sikap etis mahasiswa tersebut. Hal ini sejalan dengan penelitian Sapariyah, Setyorini dan Dharma (2016) pada mahasiswa akuntansi di Surakarta menunjukan bahwa kecerdasan kecerdasan emosional berpengaruh positif dan signifikan terhadap sikap etis mahasiswa akuntansi, tingkat kecerdasan emosi dapat meningkatkan perilaku etis mahasiswa akuntansi.

\section{$\mathrm{H}_{3}$ : Kecerdasan emosional berpengaruh didalam meningkatkan perilaku etis}

\section{Pengaruh Kecerdasan Spiritual Terhadap Perilau Etis}

Zohar dan Marshall (2007:4) mengungkapkan bahwa kecerdasan spiritual sebagai kecerdasan untuk menghadapi dan memecahkan persoalan makna dan nilai, yaitu kecerdasan untuk menempatkan perilaku dalam hidup kita dalam konteks makna yang lebih luas dan kaya, kecerdasan untuk menilai bahwa tindakan atau jalan hidup seseorang lebih bermakna dibandingkan dengan yang lain. Selain itu juga, menurut Agustian (2008:12) kecerdasan spiritual sebagai kemampuan untuk memberi makna spiritual terhadap pemikiran, perilaku dan kegiatan sehari-hari, serta mampu menyinergikan IQ, EQ, dan SQ secara komprehensip.

Hasil penelitian Riasning, dkk. (2017) pada mahasiswa akuntansi di kota Denpasar membuktikan bahwa kecerdasan spiritual memberikan pengaruh yang signifikan terhadap sikap etis mahasiswa akuntansi. Semakin tinggi tingkat kecerdasan spiritual yang dimiliki mahasiswa maka akan semakin tinggi pula sikap etis mahasiswa tersebut. Hal ini sejalan dengan penelitian Wardana dan Mimba (2016) pada mahsiswa magister akuntansi Unversitas Udayana, dimana spiritual berpengaruh positif dan signifikan terhadap sikap etis mahasiswa, tingkat kecerdasan spiritual dapat meningkatkan perilaku etis mahasiswa akuntansi.

\section{$\mathrm{H}_{4}$ : Kecerdasan spiritual berpengaruh didalam meningkatkan perilaku etis}

\section{Metode Penelitian}

Penelitian ini merupakan jenis penelitian kuantitatif dengan pendekatan deskriptif dan asosiatif, dimana terdapat variabel yang menggambarkan suatu analisis data mengenai hubugan antar variabelvariabel yang diteliti. Penelitian ini dilakukan dengan menggunakan kuesioner sebagai instrumen utama dalam pengumpulan data. Kuesioner disampaikan kepada responden secara langsung. Adapun yang menjadi populasi dalam penelitian ini adalah seluruh pegawai dilingkungan Inspektorat Provinsi Gorontalo sebanyak 89 orang. Teknik penentuan sampel yang digunakan pada penelitian ini adalah purposive sampling, teknik ini dimaksudkan untuk memperoleh sampel penelitian yang lebih representatif yang didasarkan pertimbangan atau kriteria tertentu. Kriteria sampel dalam penelitian ini adalah Auditor yang memiliki sertifikasi Jabatan Fungsional Auditor (JFA) pada Inspektorat Provinsi Gorontalo yang berjumlah 55 responden.

\section{Definisi Operasional Dan Pengukuran Variabel}

1. Locus of control internal $\left(\mathrm{X}_{1}\right)$

Menurut Robins dan Judge (2008:138) bahwa locus of control internal adalah inividu yang yakin bahwa mereka merupakan pemegang kendali atas apa pun yang terjadi pada diri mereka. Indikator yang digunakan untuk mengukur internal lcocus of control diadopsi dari teori Crider (1983) yang dikembangkan oleh Amalini, dkk. (2016:3), dengan 7 item pertanyaan menggunakan skala Likert 1 - 9 untuk setiap bobot pertanyaan.

2. Kecerdasan intelektual $\left(\mathrm{X}_{2}\right)$

Menurut Robins dan Judge (2008:56) kecerdasan intelektual adalah kemampuan yang dibutuhkan untuk melakukan berbagai aktivitas mental perpikir, nalar, dan memecahkan masalah. Pengukuran variabel ini menggunakan indikator kemampuan intelektual menurut Robins dan Judge (2008:58) yang 
juga digunakan oleh Nugroho, dkk. (2008), Widatik, dkk. (2016) dan Irsyada, dkk. (2018), dengan 7 item pertanyaan menggunakan skala Likert 1- 9 untuk setiap bobot pertanyaan.

3. Kecerdasan emosional $\left(\mathrm{X}_{3}\right)$

Menurut Goleman (2009:45) kecerdasan emosi adalah sebagai kemampuan emosi yang meliputi kemampuan untuk mengendalikan diri, memiliki daya tahan ketika menghadapi suatu masalah, mampu mengendalikan impuls, memotivasi diri, mampu mengatur suasana hati, kemampuan berempati dan membina hubungan dengan orang lain. Indikator yang digunakan dalam mengukur variabel ini adalah lima kecakapan dalam kecerdasan emosi menurut Goleman (2005:513), yang juga digunakan oleh Pasek (2016), Riasning, dkk. (2017), dan Manurung (2018), dengan 5 item pertanyaan menggunakan skala Likert 1- 9 untuk setiap bobot pertanyaan.

4. Kecerdasan spiritual $\left(\mathrm{X}_{4}\right)$

Zohar dan Marshall (2007:4) mendefinisikan kecerdasan spiritual sebagai kecerdasan untuk menghadapi dan memecahkan persoalan makna dan nilai, yaitu kecerdasan untuk menempatkan perilaku dalam hidup kita dalam konteks makna yang lebih luas dan kaya, kecerdasan untuk menilai bahwa tindakan atau jalan hidup seseorang lebih bermakna dibandingkan dengan yang lain. Indikator yang digunakan dalam mengukur variabel kecerdasan spiritual adalah menurut Zohar dan Marshall (2007:14), yang juga digunakan oleh Pasek (2016), Riasning, dkk (2017) dan Manurung (2018), dengan 9 item pertanyaan menggunakan skala Likert 1- 9 untuk setiap bobot pertanyaan.

5. Perilaku Etis $(\mathrm{Y})$

Hastuti (2007) perilaku etis merupakan tingkah laku atau tanggapan seseorang dalam lingkungan tentang hak dan kewajiban moral serta nilai-nilai benar atau salah. Indikator yang digunakan untuk mengukur variabel ini adalah prinsip - prinsip perilaku auditor APIP yang tercantum dalam Kode Etik APIP, yang juga digunakan oleh Aprilianto dan Achmad (2016), Su'udiyah (2017) dan Riasning (2017) dengan 10 item pertanyaan menggunakan skala Likert 1- 9 untuk setiap bobot pertanyaan.

\section{Hasil Penelitian Dan Pembahasan}

Pengumpulan data dalam penelitian ini dilakukan dengan menyebarkan kuesioner penelitian secara lansung kepada responden di Inspektorat Provinsi Gorontalo. Adapun jumlah kuesioner yang dibagikan sebanyak 55 kuesioner dan hanya sebanyak 44 kuesioner yang berhasil dikumpulkan, sebanyak 11 kuesioner tidak kembali.

\section{Uji Validitas Dan Reliabilitas}

Uji validitas digunakan untuk mengukur tingkat keandalan atau kesahihan suatu alat ukur, dimana kuesioner yang digunakan akan diukur tingkat validitannya terlebih dahulu. Hasil uji validitas untuk variabel Locus of Control Internal $\left(\mathrm{X}_{1}\right)$, Kecerdasan Intelektual $\left(\mathrm{X}_{2}\right)$, Kecerdasan Emosional $\left(\mathrm{X}_{3}\right)$, Kecerdasan Spiritual $\left(\mathrm{X}_{4}\right)$ dan Perilaku Etis $(\mathrm{Y})$, semuanya dinyatakan valid, karena nilai validitas berada di atas batas kritis $=2,018$ ( $\mathrm{t}_{\text {-hitung }}>\mathrm{t}$-tabel). Hasil uji reliabilitas dengan Alpha Cronbach untuk masingmasing variabel menunjukan nilai di atas batas kritis yakni 0,60 (Ghozali, 2013), sehingga dapat disimpulkan variabel Locus of Control Internal $\left(\mathrm{X}_{1}\right)$, Kecerdasan Intelektual $\left(\mathrm{X}_{2}\right)$, Kecerdasan Emosional $\left(\mathrm{X}_{3}\right)$, Kecerdasan Spiritual $\left(\mathrm{X}_{4}\right)$ dan Perilaku Etis (Y) dinyatakan reliabel.

\section{Uji Asumsi Klasik}

\section{Uji Normalitas}

Uji Kolmogorov Simirnov digunakan untuk menguji normalitas data pada penelitian ini, dengan dasar pengambilan keputusan adalah jika nilai signifikansi > 0,05, maka nilai residual berdistribusi normal. Sebaliknya, jika nilai signifikansi $<0,05$, maka nilai residual tidak berdistribusi normal. 
Tabel 1: One-Sample Kolmogorov-Smirnov Test

\begin{tabular}{|ll|l|}
\hline $\mathrm{N}$ & & Unstandardized Residual \\
Normal Parameters ${ }^{\mathrm{a}, \mathrm{b}}$ & Mean & 44 \\
& Std. Deviation & $0 \mathrm{E}-7$ \\
& Absolute & .34310205 \\
Most Extreme Differences & Positive & .078 \\
& Negative & -.088 \\
Kolmogorov-Smirnov Z & & .581 \\
Asymp. Sig. (2-tailed) & & .889 \\
\hline
\end{tabular}

Sumber: Data Olahan

Berdasarkan tabel di atas menunjukan hasil uji normalitas diketahui nilai signifikansi 0,889>0,05, maka dapat disimpulkan bahwa nilai residual berdistribusi normal.

\section{Uji Linieritas}

Kriteria pengujian linieritas adalah jika nilai signifikansi lebih kecil dari 0,05, maka hubungan antara variabel bebas dan variabel terikat adalah linier. Hasil rangkuman uji linieritas disajikan berikut ini:

Tabel 2: Rekapitulasi Hasil Uji Linieritas

\begin{tabular}{|ll|c|c|}
\hline \multicolumn{2}{|c|}{ Variabel } & Sig. & Ketarangan \\
\hline LoC Internal & $\longrightarrow$ Perilaku Etis & 0,000 & Linier \\
\hline Kecerdasan Intelektual $\longrightarrow$ Perilaku Etis & 0,000 & Linier \\
\hline Kecerdasan Emosional $\longrightarrow$ Perilaku Etis & 0,000 & Linier \\
\hline Kecerdasan Spiritual $\longrightarrow$ Perilaku Etis & 0,000 & Linier \\
\hline
\end{tabular}

Sumber: Data Olahan

Berdasarkan tabel 2 di atas, variabel Locus of Control Internal $\left(\mathrm{X}_{1}\right)$, Kecerdasan Intelektual $\left(\mathrm{X}_{2}\right)$, Kecerdasan Emosional $\left(\mathrm{X}_{3}\right)$, Kecerdasan Spiritual $\left(\mathrm{X}_{4}\right)$ terhadap variabel Perilaku Etis (Y) menunjukan kolom Sig. yang nilainya $<0,05$ maka variabel dinyatakan mempunyai hubungan yang linear dan memenuhi syarat linearitas.

\section{Uji Multikoliniearitas}

Uji multikoliniearitas pada penelitian dilakukan dengan matriks kolerasi. Pengujian ada tidaknya gejala multikolinearitas dilakukan dengan memperhatikan nilai matriks kolerasi yang dihasilkan pada saat pengolahan data serta nilai VIF (variance inflation factor) dan tolerance-nya. Apabila nilai VIF berada dibawah 10 dan nilai tolerance mendekati 1, maka diambil kesimpulan bahwa model regresi tersebut tidak terdapat masalah multikolineritas.

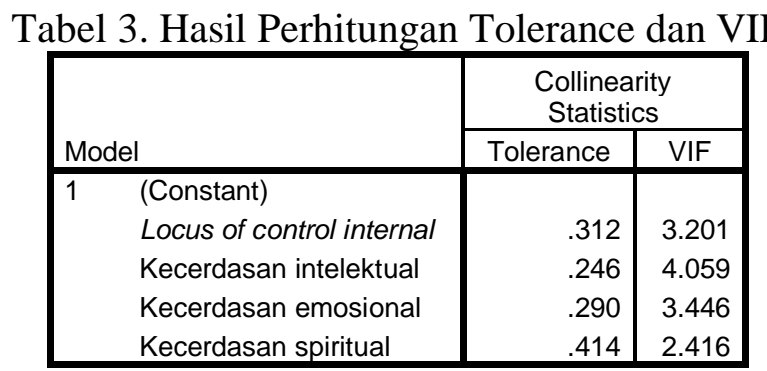

Sumber: Data Olahan

Berdasarkan tabel 4.3 di atas menunjukan masing-masing variabel memiliki nilai VIF berada dibawah 10 dan nilai tolerance mendekati 1, maka diambil kesimpulan bahwa model regresi tersebut tidak terdapat masalah multikolineritas. 


\section{Uji Autokorelasi}

Uji autokorelasi digunakan untuk mengetahui ada atau tidaknya penyimpangan asumsi klasik autokorelasi yaitu korelasi yang terjadi antara residual pada satu pengamatan dengan pengamatan lain pada model regresi. Metode pengujian yang sering digunakan adalah dengan uji Durbin-Watson (uji DW) dengan ketentuan sebagai berikut:

1) Jika d lebih kecil dari dL atau lebih besar dari (4-dL) maka hopotesis nol ditolak, yang berarti terdapat autokorelasi.

2) Jika d terletak antara dU dan (4-dU), maka hipotesis nol diterima, yang berarti tidak ada autokorelasi.

3) Jika d terletak antara dL dan dU atau diantara (4-dU) dan (4-dL), maka tidak menghasilkan kesimpulan yang pasti.

4) Nilai dU dan dL dapat diperoleh dari tabel statistik Durbin Watson yang bergantung banyaknya observasi dan banyaknya variabel yang menjelaskan.

Tabel 4. Hasil Uji Autokorelasi

\begin{tabular}{|l|r|r|r|r|r|}
\hline Model & $\mathrm{R}$ & R Square & $\begin{array}{c}\text { Adjusted R } \\
\text { Square }\end{array}$ & $\begin{array}{c}\text { Std. Error of the } \\
\text { Estimate }\end{array}$ & Durbin-Watson \\
\hline 1 & $.951^{\mathrm{a}}$ & .905 & .895 & 2.460 & 1.490 \\
\hline
\end{tabular}

a. Predictors: (Constant), Kecerdasan spiritual, Locus of control internal, Kecerdasan emosional, Kecerdasan intelektual

b. Dependent Variable: Perilaku Etis Auditor

Sumber: Data Olahan

Berdasarkan tabel 4 diatas menunjukan nilai DW sebesar 1,490 dengan keputusan nilai DW berada di antara $\mathrm{d}_{\mathrm{U}}$ sampai dengan $4-\mathrm{d}_{\mathrm{U}}$ maka koefisien autokorelasi sama dengan nol, artinya tidak ada autokorelasi. Dimana nilai $\mathrm{d}_{\mathrm{U}}=1,2437$ dan $\mathrm{d}_{\mathrm{L}}: 1,6505$, untuk nilai $\mathrm{d}_{\mathrm{U}}$ dan $\mathrm{d}_{\mathrm{L}}$ didasarkan pada tabel Durbin Wenston.

\section{Uji Heterokedastisitas}

Salah satu cara untuk mendekati heterokedastisitas adalah dengan melihat grafik scatter plot antara nilai prediksi variabel terikat (ZPRED) dengan residualnya (SRESID). Jika ada titik-titik membentuk pola tertentu yang teratur seperti bergelombang, melebar, kemudian menyempit maka telah terjadi heterokedastisitas. Jika titik-titik menyebar di atas dan di bawah angka 0 pada sumbu Y tanpa membentuk pola tertentu maka tidak terjadi heterokedastisitas.

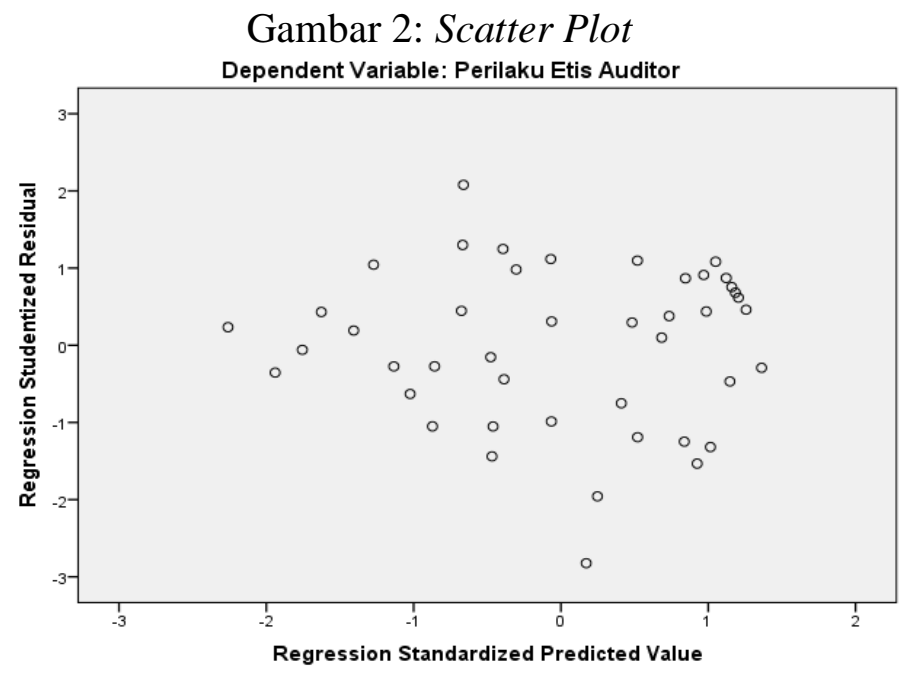


Berdasarkan gambar grafik scatter plot di atas, menunjukan titik-titik menyebar di atas dan di bawah angka 0 pada sumbu Y tanpa membentuk pola tertentu. Hasil pengujian ini maka disimpulkan bahwa model regresi tidak terjadi heterokedastisitas.

\section{Uji Hipotesis Penelitian}

Pengujian hipotesis penelitian ini ditujukan untuk mengetahaui apakah terdapat pengaruh variabel independen yakni Locus of Control Internal, Kecerdasan Intelektual, Kecerdasan Emosional dan Kecerdasan Spiritual terhadap variabel dependen yakni Perilaku Etis Auditor Inspektorat Provinsi Gorontalo.

Tabel 5. Hasil Uji Statistik Regeresi Berganda Coefficients $^{a}$

\begin{tabular}{|c|c|c|c|c|c|c|}
\hline \multirow{2}{*}{\multicolumn{2}{|c|}{ Model }} & \multicolumn{2}{|c|}{$\begin{array}{l}\text { Unstandardized } \\
\text { Coefficients }\end{array}$} & \multirow{2}{*}{$\begin{array}{c}\text { Standardized } \\
\text { Coefficients } \\
\text { Beta }\end{array}$} & \multirow[b]{2}{*}{$\mathrm{t}$} & \multirow[b]{2}{*}{ Sig. } \\
\hline & & $B$ & Std. Error & & & \\
\hline \multirow[t]{5}{*}{1} & (Constant) & 18.684 & 5.632 & & 3.317 & .002 \\
\hline & Locus of control internal & 249 & .101 & .218 & 2.466 & .018 \\
\hline & Kecerdasan intelektual & .328 & .074 & .443 & 4.455 & .000 \\
\hline & Kecerdasan emosional & .623 & .190 & .301 & 3.284 & .002 \\
\hline & Kecerdasan spiritual & .098 & .105 & .072 & .933 & .357 \\
\hline
\end{tabular}

a. Dependent Variable: Perilaku Etis Auditor

Sumber: Data Olahan

Berdasarkan tabel 5 di atas, maka dapat dibuatkan persamaan sebagai berikut:

$$
Y=18,684+0,249 X_{1}+0,328 X_{2}+0,623 X_{3}+0,098 X_{4}
$$

Berdasarkan persamaan regresi diatas, menunjukkan bahwa nilai Konstanta (Constant) sebesar 18,684, hal ini menyatakan bahwa jika tidak ada kenaikan nilai dari variabel Locus of Control Internal ( $\left.\mathrm{X}_{1}\right)$, Kecerdasan Intelektual $\left(\mathrm{X}_{2}\right)$, Kecerdasan Emosional $\left(\mathrm{X}_{3}\right)$ dan Kecerdasan Spiritual $\left(\mathrm{X}_{4}\right)$, maka nilai variabel Perilaku Etis (Y) sebesar 18,684. Koefisien variabel Locus of Control Internal $\left(\mathrm{X}_{1}\right)$ berpengaruh positif dan signifikan terhadap Perilaku Etis (Y) sebesar 0,249 atau 24,9\% dengan tingkat signifikansi 0,018 (<5\%). Koefisien variabel Kecerdasan Intelektual $\left(\mathrm{X}_{2}\right)$ berpengaruh positif dan signifikan terhadap Perilaku Etis (Y) sebesar 0,328 atau 32,8\% dengan tingkat signifikansi 0,000 $(<5 \%)$. Koefisien variabel Kecerdasan Emosional $\left(\mathrm{X}_{3}\right)$ berpengaruh positif dan signifikan terhadap Perilaku Etis (Y) sebesar 0,623 atau 62,3\% dengan tingkat signifikansi 0,002 $(<5 \%)$. Koefisien variabel Kecerdasan Spiritual $\left(\mathrm{X}_{4}\right)$ berpengaruh tidak signifikan terhadap Perilaku Etis (Y) sebesar 0,098 atau 9,8\% dengan tingkat signifikansi 0,357 $(<5 \%)$.

Tabel 6. Nilai Koefisien Determinasi Model Summary

\begin{tabular}{|l|r|r|r|c|}
\hline Model & \multicolumn{1}{|c|}{$\mathrm{R}$} & R Square & $\begin{array}{c}\text { Adjusted R } \\
\text { Square }\end{array}$ & $\begin{array}{c}\text { Std. Error of the } \\
\text { Estimate }\end{array}$ \\
\hline 1 & $.951^{\mathrm{a}}$ & .905 & .895 & 2.460 \\
\hline
\end{tabular}

a. Predictors: (Constant), Kecerdasan spiritual, Locus of control internal, Kecerdasan emosional, Kecerdasan intelektual

Sumber: Olahan Data

Nilai $R$-Square pada tabel di atas adalah 0,905, dapat diinterpretasikan bahwa variabel dependen mampu dijelaskan oleh variabel independen sebesar 90,5\%, dimana nilai $R$-Square bernilai bersar (mendekati 1) yang berarti bahwa variabel independen dapat memberikan semua informasi yang 
dibutuhkan untuk memprediksi variabel dependen. Nilai $R$ juga pada tabel di atas sebesar 0,951, menunjukan bahwa variabel independen memiliki hubungan yang kuat terhadap variabel dependen.

\section{Pembahasan}

\section{Pengaruh Locus of Control Internal Terhadap Perilaku Etis Auditor Inspektorat Provinsi Gorontalo}

Hasil analisis data statistik menunjukan variabel locus of control internal berpengaruh positif dan signifikan terhadap perilaku etis auditor pada Inspektorat Provinsi Gorontalo, sehingga secara empiris hipotesis $\left(\mathrm{H}_{1}\right)$ terbukti (diterima), dimana locus of control internal berpengaruh didalam meningkatkan perilaku etis. Hasil penelitian sejalan dengan pendapat Robbins (2011:56) locus of control adalah sampai sejauh mana orang yakin bahwa mereka menguasai nasib mereka sendiri. Locus of control merupakan konsep yang beranggapan bahwa suatu kepercayaan seseorang terkait akan perilaku serta konsekuensi yang akan dihadapinya. Hasil penelitian ini didukung dengan penelitian sebelumnya oleh Raharjo (2013) pada Kantor Akuntan Publik di Semarang menunjukan bahwa locus of control dapat mempengaruhi perilaku etis auditor, dimana semakin internal locus of control yang dimiliki seorang auditor, maka akan semakin meningkatkan perilaku etisnya. Penelitian Helmayunita (2015) juga pada Kantor Akuntan Publik di Kota Padang dan Pekanbaru juga menunjukan hasil bahwa locus of control internal berpengaruh signifikan terhadap perilaku etis akuntan. Dimana semakin tinggi tingkat locus of control internal yang dimiliki seorang akuntan maka akan meningkatkan perilaku etisnya.

2. Pengaruh Kecerdasan Intelektual Terhadap Perilaku Etis Auditor Inspektorat Provinsi Gorontalo

Hasil analisis data statistik menunjukan variabel kecerdasan intelektual berpengaruh positif dan signifikan terhadap perilaku etis auditor pada Inspektorat Provinsi Gorontalo, sehingga secara empiris hipotesis $\left(\mathrm{H}_{2}\right)$ terbukti (diterima), dimana kecerdasan intelektual berpengaruh didalam meningkatkan perilaku etis. Hasil penelitian ini sejalan dengan pendapat Binet \& Simon (dalam Azwar: 2004) bahwa intelegensi sebagai suatu kemampuan yang terdiri dari 3 komponen, yaitu: kemampuan untuk mengarahkan pikiran atau mengarahkan tindakan; kemampuan untuk mengubah arah tindakan bila tindakan itu telah dilakukan; dan kemampuan untuk mengkritik diri sendiri. Hasil penelitian ini juga didukung oleh penelitian Riasning, dkk. (2017) dan Su'udiyah (2017) yang menunjukan bahwa kecerdasan intelektual memberikan pengaruh yang signifikan terhadap sikap etis, dimana semakin tinggi tingkat kecerdasan intelektual maka akan semakin tinggi pula sikap etis seseorang.

3. Pengaruh Kecerdasan Emosional Terhadap Perilaku Etis Auditor Inspektorat Provinsi Gorontalo

Hasil analisis data statistik menunjukan variabel kecerdasan emosional berpengaruh positif dan signifikan terhadap perilaku etis auditor pada Inspektorat Provinsi Gorontalo, sehingga secara empiris hipotesis $\left(\mathrm{H}_{3}\right)$ terbukti (diterima), dimana kecerdasan emosional berpengaruh didalam meningkatkan perilaku etis. Hasil penelitian ini sejalan dengan pendapat Salovey dan Mayer (1990) kecerdasan emosi merupakan kemampuan untuk memonitor perasaan dan emosi diri sendiri dan orang lain, membedakan emosi dan perasaan, dan menggunakan informasi tersebut untuk menuntun pemikiran dan tindakan (dalam Luthans, 2006:332). Hasil ini juga sejalan dengan penelitian Riasning, dkk. (2017) dan Sapariyah, dkk (2016) dimana kecerdasan emosi memberikan pengaruh yang signifikan terhadap sikap etis. Semakin tinggi tingkat kecerdasan emosi yang dimiliki maka akan semakin tinggi pula sikap etis yang dimiliki seseorang.

4. Pengaruh Kecerdasan Spiritual Terhadap Perilaku Etis Auditor Inspektorat Provinsi Gorontalo Hasil analisis data statistik menunjukan variabel kecerdasan spiritual tidak berpengaruh signifikan terhadap perilaku etis auditor pada Inspektorat Provinsi Gorontalo, sehingga secara empiris hipotesis $\left(\mathrm{H}_{4}\right)$ tidak terbukti (ditolak), dimana kecerdasan spiritual berpengaruh didalam meningkatkan perilaku etis. Hasil penelitian ini tidak sejalan dengan pendapat Zohar dan Marshall (2007:4) dimana orang yang memiliki kecerdasan spiritual tinggi mampu memaknai hidup dengan memberi makna positif pada setiap peristiwa, masalah, bahkan penderitaan yang dialaminya. Dengan memberi makna yang positif akan mampu membangkitkan jiwa dan melakukan perbuatan dan tindakan yang positif. Namun 
demikian, beberapa penelitian sebelumnya menunjukan hasil yang sama, dimana hasil penelitian Ishak (2018) dan Wigneswara (2016) menunjukan variabel kecerdasan spiritual tidak memberikan pengaruh yang signifikan terhadap perilaku etis auditor.

\section{Kesimpulan Dan Saran}

Secara keseluruhan hasil penelitian ini dapat disimpulkan sebagai berikut:

1. Locus of Control Internal berpengaruh dalam meningkatkan perilaku etis Audtior Inspektorat Provinsi Gorontalo. Hipotesis yang diajukan terbukti dan diterima.

2. Kecerdasan Intelektual (IQ) berpengaruh dalam meningkatkan perilaku etis Audtior Inspektorat Provinsi Gorontalo. Hipotesis yang diajukan terbukti dan diterima.

3. Kecerdasan Emosional (EQ) berpengaruh dalam meningkatkan perilaku etis Audtior Inspektorat Provinsi Gorontalo. Hipotesis yang diajukan terbukti dan diterima.

4. Kecerdasan Spiritual (SQ) tidak berpengaruh dalam meningkatkan perilaku etis Audtior Inspektorat Provinsi Gorontalo. Hipotesis yang diajukan tidak terbukti dan ditolak.

Saran-saran konstruktif dalam peneitian ini adalah perlu adanya sebuah form penilaian tersendiri terhadap etika auditor berdasarkan Kode Etik APIP, sehingga perilaku auditor berdasarkan prinsi-prinsip etis dapat diaktualisasi. Hasil penelitian menunjukan tingkat kecerdasan spiritual tidak memberikan dampak yang signifikan terhadap perilaku etis. Nilai-nilai spiritual seorang auditor dapat tercermin melalui integritas diri, sehingga upaya evaluasi etika auditor dan upaya-upaya lainnya, dalam rangka meningkatkan nilai-nilai spiritual dalam diri auditor penting dilakukan, guna untuk meningkatkan kinerja auditor. Selain itu juga, penting dilakukan sebuah penelitian lebih mendalam sehubungan dengan nilai-nilai spiritualitas auditor APIP dalam lingkungan kerja. Terutama berkaitan dengan upaya untuk meningkatkan nilai spiritual auditor dalam lingkungan kerja dan paradigma tentang nilai spiritualitas dalam meningkatkan integritas dan produktivitas kerja seorang auditor. Auditor dengan tingkat kecerdasan spiritual akan memiliki tingkat kesadaran diri yang tinggi terhadap tugas dan tanggung jawabnya serta terhadap diri dan lingkungannya. Tingkat kecerdasan spiritual yang tinggi dapat mengatasi berbagai permasalahan etika yang terjadi dalam lingkungan kerja auditor, nilai-nilai spiritual akan menjadi unsur penguat didalam meningkatkan integritas dan sikap profesionalisme seorang auditor dalam melaksanakan tugasnya.

\section{Daftar Pustaka}

Agustian, Ary Ginanjar. 2008. Rahasia Sukses Membangun Kecerdasan Emosi dan Spiritual the ESQ Way 165. Jakarta: Arga Wijaya Persada.

Amalini, H.F., Musadieq, M.A., Afrianty, T.W. 2016. Pengaruh Locus of Control Terhadap Kepuasan Kerja Dan Kinerja. Studi Pada Karyawan Perusahaan Daerah Air Minum (PDAM) Kota Malang. Jurnal Administrasi Bisnis, Vol. 35 No.1

Aprilianto, R. dan Achmand, T. 2017. Pengaruh Kecerdasdan Emosional, Kecerdasan Intelektual Dan Love of Money Terhadap Persepsi Mahasiswa Mengenai Etika Provesi Akuntan. Diponegoro Jurnal of Accounting. Vol. 6 No. 2.

Azwar, S. 2004. Pengantar Psikologi Intelegensi, Cetakan Kelima. Yogyakarta: Pustaka Pelajar.

Ghozali, I. 2013. Aplikasi Analisis Multivariate dengan Program IBM SPSS 21 Update PLS Regresi. Semarang: Badan Penerbit Universitas Diponegoro.

Goleman, Daniel. 2009. Kecerdasan Emosional: Mengapa EI lebih penting dari pada IQ. Jakarta: PT. Gramedia Pustaka Utama. 
Hastuti, S. 2007. Perilaku Etis Mahasiswa dan Dosen Ditinjau Dari Faktor Individual Gender dan Locus of Control (Studi Empiris pada Fakultas Ekonomi Universitas X di Jatim). Jurnal Riset Ekonomi dan Bisnis. Vol. 7 No. 1.

Helmayunita, N. 2015. Pengaruh Orientasi Etika, Dan Locus of Control Terhadap Perilaku Etis Akuntan. Jurnal Praktik Bisnis, Volume 4, Nomor 1, Mei 2015, ISSN 2302-9242.

Irsyada, M.R., Sunaryo, H., Priyono, A.A. 2018. Kecerdasan Intelektual, Kecerdasan Emosional dan Kecerdasan Spiritual Pengaruhnya Terhadap Kinerja Karyawan. E-Journal Riset Manajemen, Fakultas Ekonomi Unisma.

Ishak, Parmin. 2018. Pengaruh Independensi Auditor, Emotional Intelligence, Spiritual IntelligenceTerhadap Perilaku Etis Auditor dan Kinerja Auditor. Jurnal Ilmiah Akuntansi ATESTASI Vol. 1No. 1 September 2018

Jones, G.R. and George, J.M. 2011. Contemporary Management. Boston: McGraw Hill.

Kneefel, E., Sondakh, J. J., Mawikere, L. 2017. Pengaruh Kode Etik APIP Terhadap Kinerja Auditor Pemerintah Pada Inspektorat Provinsi Maluku Utara. Jurnal Riset Akuntansi Going Concern Vol 12(2)

Luthans, Freds. 2006. Perilaku Organisasi. Edisi Sepuluh, PT. Andi: Yogyakarta.

Manurung, Ria. 2018. Analisis Pengaruh Kecerdasan Intelektual Terhadap Kemampuan Akuntansi Dengan Kecerdasan Emosional Dan Spiritual Sebagai Pemoderasi. Jurnal Keuangan Dan Bisnis. Maret:2018.

Mulyadi. 2010. Auditing. Edisi Kenam. Buku 1. Jakarta: Salemba Empat.

Nugroho, P.I., Suharti, L., Laksana, T.E. 2008. Pengaruh Kemampuan Intelektual Dan Kemampuan Emosional Terhadap Kinerja Auditor Melalui Kepuasan Kerja Sebagai Variabel Intervening. Jurnal Ekonomi Dan Bisnis Vol. XIV No.2 September 2008.

Pasek, N.S. 2016. Pengaruh Kecerdasan Intelektual Pada Pemahaman Akuntansi Dengan Kecerdasan Emosional dan Kecerdasan Spiritual Sebagai Variabel Pemoderasi. Jurnal Ilmiah Akuntansi. Vol. 1. No.1 Juni:2016.

Peraturan Menteri Pemberdayaan Aparatur Negara No. 4 Tahun 2008 tentang Kode Etik APIP

Raharjo, E. M. T. 2013. Pengaruh Locus of Control, Pengalaman Kerja Dan Sistem Reward Terhadap Perilaku Etis Auditor. Jurnal Akuntansi Bisnis, Vol. XI No. 22 Maret 2013.

Riasning, N. P., Datrini, L. K., Putra, I M, W. 2017. Pengaruh Kecerdasan Intelektual, Kecerdasan Emosional Dan Kecerdasan Spiritual Terhadap Sikap Etis Mahasiswa Akuntansi Di Kota Denpasar. Jurnal KRISNA: Kumpulan Riset Akuntansi; Vol. 9. No. 1 Juli 2017.

Reiss, M. C. dan Mitra, K. 1998. The Effect of Individual Difference Faktors on the Acceptibility of Ethical and Unethical Workplace Behaviors. Journal of Business Ethics 17: 1581.

Robbins, S.P. 2011. Perilaku Organisasi. Jakarta: Salemba Empat.

Robbins, P. S. dan Judge, A. T. 2008. Prilaku Organisasi. Edisi Dua Belas. Jakarta: Salemba Empat.

Rotter, J. B. 1982. The development and applications of social learning theory. New York: Praeger.

--------. 1966. Generalized Expectancies for Internal Versus External Control Reinforcement, Psychology Monographs: General Applied.

Sapariyah, A. R., Setyorini, Y., Dharma, A. B. 2016. Pengaruh Muatan Etika Dalam Pengajaran Akuntanasi Keuangan, Kecerdasan Intelektual, Kecerdasan Emosional Dan Kecerdasan Spiritual Terhadap Sikap Etis Mahasiswa Akuntansi. Jurnal Paradigma Vol 13, No. 02 - 2016.

Su'udiyah, A. 2017. Pengaruh Kecerdasan Intelektual (IQ), Kecerdasan Emosional (EQ) Dan Kecerdasan Spiritual (SQ) Terhadap Sikap Etis Mahaisswa Akuntansi. Menara Ilmu. Vol. XI Jilid 1 No. 77.

Suryaningrum et al. 2013. Accounting Student And Lecturer Ethical Behavior: Evidence From Indonesia. Business Education \& Accreditation. Volume 5. Number 1.

Wardana dan Mimba. 2016. Pengaruh Kecerdasan Intelektual, Kecerdasan Emosional, Kecerdasan Spiritual Dan Gender Terhadap Sikap Etis Mahasiswa Magister Akuntansi Universtas Udayana. E-Jurnal Ekonomi dan Bisnis Universitas Udayana 5.10. 
Widatik, C., Rispantyo, Kristianto, D. 2016. Pengaruh Kecerdasan Emosional, Kecerdasan Intelektual, Kecerdasan Spiritual, Kecerdasan Sosial Terhadap Pemahaman Akuntansi. Program Studi Akuntansi FE Universtas Slamet Riyadi Surakarta.

Wigneswara, A. S. 2016. Pengaruh IQ, EQ dan SQ Terhadap Perilaku Etis Auditor Eksternal Pada KAP Di Surabaya., Universitas Airlangga. http://repository.unair.ac.id/52832/

Zohar, D. dan Marshall, I. 2007. SQ: Memanfaatkan SQ Dalam Berpikir Holistic Untuk Memaknai Kerhidupan. Bandung: Mizan. 